Agro-Science Journal of Tropical Agriculture, Food, Environment and Extension ISSN 1119-7455

\title{
EFFECTS OF ENRICHED ORGANIC MANURE ON N- FIXING ABILITY OF COWPEA (Vigna unguiculata (L) Walp) GROWN IN MAIZE MIXTURE
}

\author{
Olatunji, $O^{*}$ and Anjembe B.C. \\ Department of Soil Science, University of Agriculture, P.M.B 2373, Makurdi \\ Benue State, Nigeria
}

\begin{abstract}
Field experiments were carried out during the 2008 and 2009 cropping seasons to evaluate the effects of enriched organic manure on both nodule count and $N$-fixing ability of two varieties of cowpea (ITAS EARLY and IAR 1060). The treatments were: poultry manure $\left(0,3\right.$, and 6 t ha $\left.{ }^{-1}\right)$; NPK 20-10-10

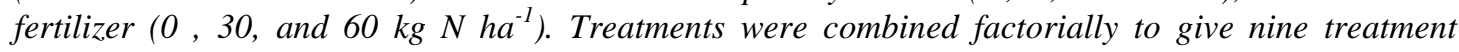
combinations. The experiments were laid-out in a randomized complete block design (RCBD) with three replications. Each experiment plot measured $3 \mathrm{~m} \times 4 \mathrm{~m}$ with an alley of $1 \mathrm{~m}$ between blocks and $0.5 \mathrm{~m}$ between plots. Four seeds were planted per hole at $25 \mathrm{~cm}$ plant-to-plant distance in a maize mixture and later thinned to two plants per stand at two weeks after planting (2 WAP).,This gave a total population of about 80, 000 plants per hectare. The nodule count and $N$-fixed were determined at 3, 6, and 12 weeks after planting (WAP). The results showed that the combined NPK 20-10-10 with poultry manure contributed to the differences $(P<0.05)$ in number of count obtained per plant of cowpea as well as the amount of N-fixed in the experiment. The higher rates of NPK 20-10-10 fertilizer, number tend to reduce the number of nodules as well as the amount of $N$-fixed. The highest nodules (86.6 and 102.2) and N-fixed (42.05 and $\left.59.50 \mathrm{~kg} \mathrm{~h}^{-1}\right)$ for 2008 and 2009, respectively were from the combination of $6 t \mathrm{ha}^{-1}$ of poultry manure and no NPK 20-10-10 fertilizer application on cowpea variety, ITAS EARLY. This suggested that cowpea variety (ITAS EARLY) tolerated high nutrient in N-fixation and as such a better choice as a leguminous component than IAR 1060 in a cropping system.
\end{abstract}

Keywords: Enriched organic manure, N-fixation, nodules count, cowpea varieties

\section{INTRODUCTION}

The use of food and non-grain legume species in cropping systems has been demonstrated to have positive attributes especially as soil ameliorants. Cowpea being a legume crop, derives all its nitrogen requirement from the atmosphere. Root nodules formed by soil rhizobia present in the soil are enough to effect sufficient nodulation. Ojiem et al. (2007) observed that the amount of $\mathrm{N}_{2}$ fixed by a legume crop varies widely because it depends on the legume genotype, rhizobium strain and the soil environment. To ensure productivity and increase in crop yield, Ande et al. (2008) suggested that appropriate systems and inputs such as organic, inorganic and biological fertilizers be adequately understood. Legumes commonly form a symbiosis with species of the bacterial family Rhizobiaceae, which can result in an efficient biological nitrogen fixation system. Most of the tropical species are nodulated by rhizobia of the
'Cowpea Miscellany'. (Giller et al., 1998). Available research results have consistently demonstrated the ability of the legume species when integrated into cropping systems to enhance $\mathrm{N}$-fixation and $\mathrm{N}$-transfer and most often with exertion of $\mathrm{N}$-sparring effects. The introduction of $\mathrm{N}_{2}$-fixing legumes systems can therefore serve as a cheap, and renewable source of $\mathrm{N}$ for the non-fixing crops involved in such systems (Ogoke et al., 2001; Cheruiyot et al., 2003). The overall cumulative advantages were increase in yield, improved resource use, efficiency of high economic values, crop diversification and reduced environmental pollution. In practical field situations, the use of food legumes as components in the system significantly improved the yield of the cereal components.

The ability of legumes to fix $\mathrm{N}_{2}$ will not prevent fertilization when grown in association with cereals that require more nutrients in terms 
of NPK, and this will invariably have negative effect on the nodulation and $\mathrm{N}$-fixing ability of the legumes. It is therefore imperative to select legumes that will optimize biological nitrogen fixation according to the needs and constraints of the cropping system as well as the area involve in the cultivation.

There are many reported studies on the effects of $\mathrm{P}$ application on growth and yield of cowpea (Owolade et al., 2006; Kolawole et al., 2002), but there is little information on the combined effect of organic and mineral fertilizers on nodulation and $\mathrm{N}$-fixing ability of cowpea.

This study was therefore designed to evaluate the effects of enriched organic manure with NPK 20-10-10 on both the nodules count and N-fixing ability of two cowpea varieties grown in maize mixture.

\section{MATERIALS AND METHODS}

Site

The field experiments were sited at the Experimental Farm of the University of Agriculture, Makurdi $\left(7^{0} 41^{\prime} \mathrm{N}, 8^{0} 35^{\prime} \mathrm{E}\right)$ in the Southern Guinea agro-ecological zone of Nigeria. The soil was classified as Typic Ustropept.

\section{Field experiment}

The experiments were conducted during the 2008 and 2009 cropping seasons and were laid out in a randomized complete block design with three replications.

The plot size was $4 \mathrm{~m} \times 3 \mathrm{~m}$ (four ridges per plot).The treatments (9) were the following:

$\mathrm{P}_{0} \mathrm{~F}_{0}$ - Control

$\mathrm{P}_{0} \mathrm{~F}_{1}-30 \mathrm{~kg} \mathrm{~N}^{-1}$ NPK 20-10-10

$\mathrm{P}_{0} \mathrm{~F}_{2}-60 \mathrm{~kg} \mathrm{~N}^{-1}$ NPK 20-10-10

$\mathrm{P}_{1} \mathrm{~F}_{0}-3 \mathrm{tha}^{-1}$ poultry manure

$\mathrm{P}_{1} \mathrm{~F}_{1}-3 \mathrm{t} \mathrm{ha}^{-1}$ poultry manure $+30 \mathrm{~kg} \mathrm{~N}^{-1}$ NPK 20-10-10

$\mathrm{P}_{1} \mathrm{~F}_{2}-3 \mathrm{t} \mathrm{ha}^{-1}$ poultry manure $+60 \mathrm{~kg} \mathrm{~N} \mathrm{ha}^{-1}$ NPK 20-10-10

$\mathrm{P}_{2} \mathrm{~F}_{0}-6 \mathrm{tha}^{-1}$ poultry manure

$\mathrm{P}_{2} \mathrm{~F}_{1}-6 \mathrm{t} \mathrm{ha}^{-1}$ poultry manure $+30 \mathrm{~kg} \mathrm{~N}^{-1}$ NPK 20-10-10

$\mathrm{P}_{2} \mathrm{~F}_{2}-6 \mathrm{t} \mathrm{ha}^{-1}$ poultry manure $+60 \mathrm{~kg} \mathrm{~N}^{-1}$ NPK 20-10-10

The sites were cleared manually using cutlass and later ridged with hoe. Poultry manure as a sole treatment and the half of NPK 20-10-10 (30 $\mathrm{kg} \mathrm{ha}^{-1}$ and $60 \mathrm{~kg} \mathrm{ha}^{-1}$ ) combined with poultry manure ( 3 and $6 \mathrm{t} \mathrm{ha}^{-1}$ ) were uniformly spread on top of the ridge $(0.75 \mathrm{~m}$ apart $)$ and incorporated into the soil with hoe two weeks before planting. Planting was done in the month of August for the two seasons. Four cowpea seeds (two varieties; ITAS EARLY and IAR 1060) were planted $25 \mathrm{~cm}$ plant -to-plant distance in a maize mixture and later thinned to two plants per stand at two weeks after planting (2 WAP), this gave a total population of about 80,000 plants per hectare.

\section{Soil sampling, soil analysis and poultry} manure

Before planting in 2008 surface $(0-15 \mathrm{~cm})$ soil samples were collected from 8 points and bulked. The soil samples and poultry manure applied was analyzed. The soil samples and the poultry manure sample were air-dried, crushed and allowed to pass through $2 \mathrm{~mm}$ sieve. Particle size distribution was carried out using Hydrometer method (Bouyoucos, 1951), while soil $\mathrm{pH}$ was measured with the glass electrode $\mathrm{pH}$ in soil solution ratio of $1: 2$ in $0.01 \mathrm{M} \mathrm{CaCl}_{2}$. Soil organic carbon (OC) was determined using the Walkey-Black (1934) method and the total N by the micro-Kjeldahl digestion method (Bremner and Mulvaney, 1982) after digestion of samples with concentrated $\mathrm{H}_{2} \mathrm{SO}_{4}$. Available $\mathrm{P}$ was determine using Bray and Kurtz, (1945) extraction method. Exchangeable cations were extracted using $1 \mathrm{~N} \mathrm{NH}_{4} \mathrm{OAC}$ solution with $\mathrm{K}$ and $\mathrm{Na}$ read using flame Photometer, while $\mathrm{Ca}$ and $\mathrm{Mg}$ were determined on the atomic absorption Spectrophotometer. Effective cation exchange capacity (ECEC) was established as summation of the excheageable cations $(\mathrm{K}, \mathrm{Na}$, $\mathrm{Ca}$ and $\mathrm{Mg}$ ). The poultry manure used for the experiment was collected in dried form from a broiler poultry pen. The nitrogen of the poultry manure sample was determined using microKjeldahl method. For the determination of P, 5 $\mathrm{ml}$ of sample solution from wet digestion was used. Phosphorus was determined using VanadoMolybdate Colorimetry Method. The K, Ca and $\mathrm{Na}$ in the sample was determined using flame Photometer (AOAC, 1990), and $\mathrm{Mg}$ was determined using Atomic Absorption Spectrometer (AAS).

\section{Crop Sampling}

Destructive samplings were carried out on both cowpea varieties and maize in the control plot at 3 weeks after planting ( 3 WAP), 6 weeks after planting (6 WAP) and at harvest to determine amount of $\mathrm{N}$-fixed by cowpea. From each plot cowpea plants were carefully uprooted with hoe to the rooting depth and taken to the laboratory. The nodules were counted, then $\mathrm{N}$ in leaves, shoot and roots were determined. The maize plant in the control plot was uprooted at each sampling period to serve as non-fixing reference crop.

\section{Plant Tissue Analysis}

Cowpea plants and maize that were uprooted at 3 WAP, 6 WAP and harvest, the leaves, shoot 
Olatunji, $\mathrm{O}$ and Anjembe B.C.

and roots were ground after oven dried at $110^{\circ} \mathrm{C}$ for 24 hours using mortar and pestle. The materials were sieved using 40-mesh screen after which they were subjected to analysis. Total plant nitrogen was determined using MicroKjeldahl Method.

\section{Estimation of $\mathbf{N}$-fixed by cowpea}

Estimation of nitrogen fixed was determined using equation described by Hauser (1990) called extended $\mathrm{N}$ difference method.

Estimates of fixed nitrogen are calculated by this equation:

$\mathrm{N}_{\text {(fixed) }}=\mathrm{N}_{\text {(cowpea) }}-\mathrm{N}_{\text {ref (maize) }}$

The $\mathrm{N}$ in leaves, roots of legumes and reference crop are included in consideration of the total $\mathrm{N}$ fixed.

\section{Data Analysis}

The statistical analysis was performed using SPSS statistical package for the analysis of variance (ANOVA). Means were separated using Fisher's Least Significant Difference. FLSD at 0.05 level of probability where F-ratio was significant.

\section{RESULTS}

\section{Poultry manure and soil properties}

The poultry manure contained $14.8 \% \mathrm{C}, 2.42 \%$ $\mathrm{N}, 1.65 \% \mathrm{P}, 2.45 \% \mathrm{~K}, 16.50 \% \mathrm{Ca}$ and $0.75 \%$ $\mathrm{Mg}$, the physical and chemical properties of the soil on which the experiment was carried out are shown in Table 1. The soil was sandy loam, slightly acidic and very low in organic $\mathrm{C}$, the total $\mathrm{N}$ was very low and the available $\mathrm{P}$ and exchangeable $\mathrm{K}$ values were low for the production of maize but cowpea can tolerate the prevailing soil conditions

\section{Nodules Count of Cowpea (ITAS EARLY)}

The application of poultry manure and NPK 2010-10 contributed to the differences in the number of nodules count obtained per plant of cowpea (ITAS EARLY) in 2008 and 2009 (Figure 1). The highest nodules counts were obtained at 6 WAP which corresponded to the time the cowpea plants were at full bloom. The result shows that least nodules count were obtained at 3 WAP sampling period. The nodules count obtained at 12 WAP were more than that of 3 WAP but less than that of 6 WAP. The nodules count had the following trend; 6 WAP > 12 WAP .3 WAP. In 2008 at 6 WAP the highest average count was obtained from $6 \mathrm{t} \mathrm{ha}^{-1}$ poultry manure (85.6), this was followed by $3 \mathrm{t}$ $\mathrm{ha}^{-1}$ poultry manure (68.8) and the third highest was obtained from $3 \mathrm{t} \mathrm{ha}^{-1}$ poultry manure +60 $\mathrm{kg} \mathrm{N}^{-1} \mathrm{NPK} 20-10-10$ (52.5), while in 2009 at 6 WAP the highest average count was obtained from $6 \mathrm{t} \mathrm{ha}^{-1}$ poultry manure (102.2), the second highest count from $3 \mathrm{t} \mathrm{ha}^{-1}$ poultry manure (82.1), while the third highest average count was obtained from $3 \mathrm{t} \mathrm{ha}^{-1}$ poultry manure $+60 \mathrm{~kg} \mathrm{~N}$ $\mathrm{ha}^{-1}$ NPK 20-10-10 (59.7). in both year, 2008 and 2009 the trend observed was as follow: $6 \mathrm{t}$ $\mathrm{ha}^{-1}$ poultry manure $>3 \mathrm{t} \mathrm{ha}^{-1}$ poultry manure $>3$ $\mathrm{t}^{-1} \mathrm{a}^{-1}$ poultry manure $+60 \mathrm{~kg} \mathrm{~N}^{-1} \mathrm{NPK} 20-10-$ 10 , the control had the least count for both year; 11.1 and 13.3 for 2008 and 2009 respectively

\section{Table 1: Soil physical and chemical} properties before planting

\begin{tabular}{ll}
\hline Properties & Values \\
\hline $\mathrm{pH}(\mathrm{H} 2 \mathrm{O})$ & 6.20 \\
$\mathrm{pH}(\mathrm{CaCl} 2)$ & 5.90 \\
$\%$ sand & 75.60 \\
$\%$ Silt & 17.20 \\
$\%$ Clay & 7.20 \\
Textural Class & Sandy loam \\
$\mathrm{N}(\mathrm{g} \mathrm{Kg}-1)$ & 0.09 \\
$\mathrm{P}(\mathrm{mg} \mathrm{Kg}-1)$ & 2.15 \\
$\mathrm{~K}(\mathrm{cmol} \mathrm{Kg}-1)$ & 0.22 \\
$\mathrm{Ca}(\mathrm{cmol} \mathrm{Kg}-1)$ & 2.60 \\
$\mathrm{Mg}(\mathrm{cmol} \mathrm{Kg}-1)$ & 2.48 \\
$\mathrm{Na}(\mathrm{cmol} \mathrm{Kg}-1)$ & 0.31 \\
$\mathrm{ECEC} \mathrm{(cmol} \mathrm{Kg-1)}$ & 6.48 \\
$\mathrm{OC}(\mathrm{g} \mathrm{Kg}-1)$ & 1.25 \\
$\mathrm{OM}(\mathrm{g} \mathrm{Kg}-1)$ & 1.45 \\
\hline
\end{tabular}

\section{Nodules Count of Cowpea (IAR 1060)}

The effects of the poultry manure enriched with NPK 20-10-10 on the nodules count per plant of cowpea (IAR 1060) are shown in (Figure 2). A significant response $(\mathrm{P}<0.05)$ was equally observed in the average nodules count per plant as was observed for cowpea (ITAS EARLY). The nodules count result obtained under cowpea (IAR 1060) was not as high as the one obtained under cowpea (ITAS EARLY). In 2008 at 3 WAP treatment $60 \mathrm{~kg} \mathrm{~N}^{-1}$ NPK 20-10-10 had no nodules. In 2008 at 6 WAP the highest average count was obtained from treatment $6 \mathrm{t}$ $\mathrm{ha}^{-1}$ poultry manure (44.9), this was followed by treatment $3 \mathrm{t} \mathrm{ha}^{-1}$ poultry manure $+60 \mathrm{~kg} \mathrm{~N}^{-1}$ NPK 20-10-10 (42.4) and the third highest count was obtained from treatment $3 \mathrm{t} \mathrm{ha}^{-1}$ poultry manure (36.1), while the least count was obtained from treatment $60 \mathrm{~kg} \mathrm{~N} \mathrm{ha}^{-1} \mathrm{NPK} 20$ 10-10 (14.2). The trend obtained under cowpea (IAR 1060) for both years did not follow a definite pattern as observed under cowpea (ITAS). 
Effects of Enriched Organic Manure on N- Fixing Ability of Cowpea
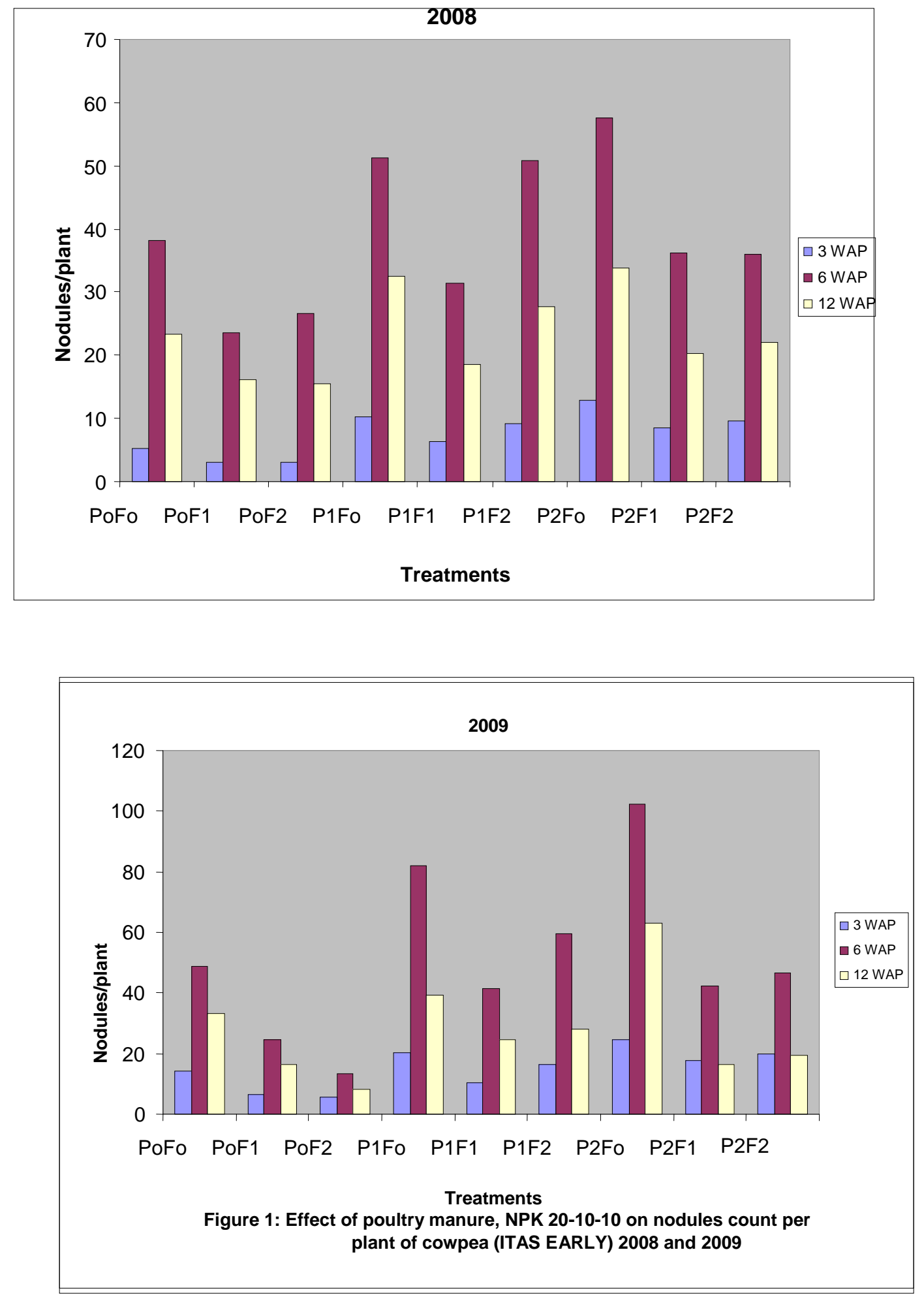

Key:

$\mathrm{P}_{0}-0 \mathrm{t} \mathrm{ha}^{-1}$ poultry manure

$\mathrm{F}_{0^{-}} 0 \mathrm{~kg} \mathrm{~N} \mathrm{Na}^{-1} \mathrm{NPK} 20-10-10$

$\mathrm{P}_{1}-3 \mathrm{t} \mathrm{ha}^{-1}$ poultry manure

$\mathrm{F}_{1}-30 \mathrm{~kg} \mathrm{~N} \mathrm{ha}^{-1}$ NPK $20-10-10$

$\mathrm{P}_{2}-6 \mathrm{tha}^{-1}$ poultry manure

$\mathrm{F}_{2}-60 \mathrm{~kg} \mathrm{~N} \mathrm{ha}^{-1}$ NPK 20-10-10 

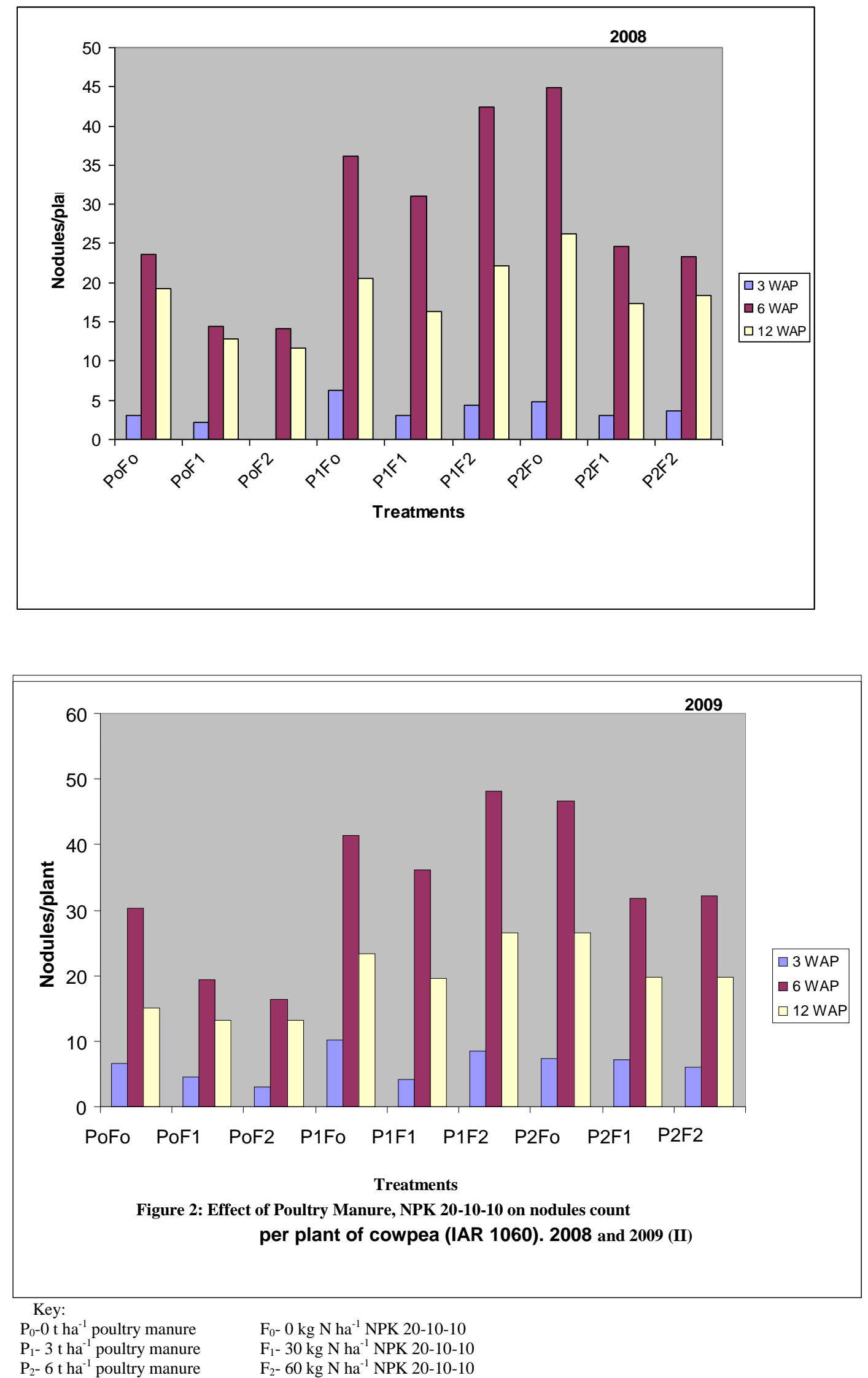
Effects of Enriched Organic Manure on N- Fixing Ability of Cowpea

\section{N-Fixed by cowpea variety (ITAS EARLY)}

Enriched poultry manure contributed to differences observed in the amount of N-Fixed by cowpea variety (ITAS EARLY) in 2008 and 2009 (Figure 3). There was positive relationship between the nodules count observed and the amount of N-Fixed. However, there were places where nodules were found, but no N-Fixed. This suggests that nodule formation may not be ultimate in N-Fixation processes. The N-Fixed at the three stages of determination showed that $\mathrm{N}$ fixed at 6 WAP was the highest across all the treatments in both years; 2008 and 2009. The following trend was observed; $6>12>3 \mathrm{WAP}$ for 2008 and 2009 respectively. In 2008 at 6 WAP the highest $\mathrm{N}$-fixed was obtained from treatment $6 \mathrm{t} \mathrm{ha}^{-1}$ poultry manure $\left(42.05 \mathrm{~kg} \mathrm{ha}^{-1}\right)$, the second highest was from treatment $3 \mathrm{t} \mathrm{ha}^{-1}$ poultry manure $\left(40.25 \mathrm{~kg} \mathrm{ha}^{-1}\right)$ and the third highest from treatment $3 \mathrm{t} \mathrm{ha}^{-1}$ poultry manure + $60 \mathrm{~kg} \mathrm{~N}$ ha $^{-1}$ NPK 20-10-10 (30.60 kg ha ${ }^{-1}$ ), while in 2009 at 6 WAP the highest $\mathrm{N}$-fixed was obtained from $6 \mathrm{t} \mathrm{ha}^{-1}$ poultry manure $(59.50 \mathrm{~kg}$ $\left.\mathrm{ha}^{-1}\right)$, the second highest from $3 \mathrm{t} \mathrm{ha}^{-1}$ poultry manure $\left(44.21 \mathrm{~kg} \mathrm{ha}^{-1}\right)$ and the third highest was obtained from $3 \mathrm{t} \mathrm{ha}^{-1}$ poultry manure $+60 \mathrm{~kg} \mathrm{~N}$ $\mathrm{ha}^{-1}$ NPK 20-10-10 (32.61 kg ha $\left.{ }^{-1}\right)$. The least Nfixed in 2008 and 2009 was obtained from treatment $3 \mathrm{t} \mathrm{ha}^{-1}$ poultry manure $+60 \mathrm{~kg} \mathrm{~N} \mathrm{ha}^{-1}$ NPK 20-10-10: $10.25 \mathrm{~kg} \mathrm{ha}^{-1}$ and $11.52 \mathrm{~kg} \mathrm{ha}^{-1}$ for 2008 and 2009 respectively.

\section{N-Fixed by cowpea variety (IAR 1060)}

The amount of $\mathrm{N}$-fixed by cowpea variety (IAR 1060) in 2008 and 2009 is presented in (Figure $4)$. The trend of N-fixed was the same observed for cowpea variety (ITAS EARLY); $6>12>3$ WAP. It was observed that there were treatments in 2008 at $3 \mathrm{WAP}$ that no $\mathrm{N}$ was fixed $(60 \mathrm{~kg} \mathrm{~N}$ $\mathrm{ha}^{-1}$ NPK 20-10-10, $3 \mathrm{t} \mathrm{ha}^{-1}$ poultry manure +30 $\mathrm{kg} \mathrm{N} \mathrm{ha}{ }^{-1}$ NPK 20-10-10 and $6 \mathrm{t} \mathrm{ha}^{-1}$ poultry manure + $\left.60 \mathrm{~kg} \mathrm{~N}^{-1} \mathrm{NPK} 20-10-10\right)$. In 2008 at 6 WAP the highest $\mathrm{N}$-fixed was obtained from treatment $6 \mathrm{t} \mathrm{ha}^{-1}$ poultry manure $\left(30.15 \mathrm{~kg} \mathrm{ha}^{-1}\right)$, the second highest was from treatment $3 \mathrm{t} \mathrm{ha}^{-1}$ poultry manure $+60 \mathrm{~kg} \mathrm{~N}^{-1} \mathrm{NPK} 20-10-10$ $\left(29.10 \mathrm{~kg} \mathrm{ha}^{-1}\right)$ and the third highest from treatment $3 \mathrm{t} \mathrm{ha}^{-1}$ poultry manure $\left(22.62 \mathrm{~kg} \mathrm{ha}^{-1}\right)$. The least came from treatment $30 \mathrm{~kg} \mathrm{~N}^{-1} \mathrm{NPK}$ 20-10-10 (12.58 $\left.\mathrm{kg} \mathrm{ha}^{-1}\right)$. In 2009 at 6 WAP the highest $\mathrm{N}$-fixed was obtained from treatment $6 \mathrm{t}$ $\mathrm{ha}^{-1}$ poultry manure $\left(30.28 \mathrm{~kg} \mathrm{ha}^{-1}\right)$, the second highest was obtained from treatment $3 \mathrm{t} \mathrm{ha}^{-1}$ poultry manure $+60 \mathrm{~kg} \mathrm{~N}^{-1} \mathrm{NPK} 20-10-10$ (29.52 $\mathrm{kg} \mathrm{ha}^{-1}$ ) and the third highest was obtained from $3 \mathrm{t} \mathrm{ha}^{-1}$ poultry manure $(28.95 \mathrm{~kg}$ $\mathrm{ha}^{-1}$ ), while the least $\mathrm{N}$-fixed was from treatment $30 \mathrm{~kg} \mathrm{~N} \mathrm{ha}{ }^{-1}$ NPK 20-10-10 (15.90 kg ha $\left.{ }^{-1}\right)$. It was observed that the values of $\mathrm{N}$-fixed under cowpea variety (IAR 1060) were lower than that of cowpea variety (ITAS EARLY).

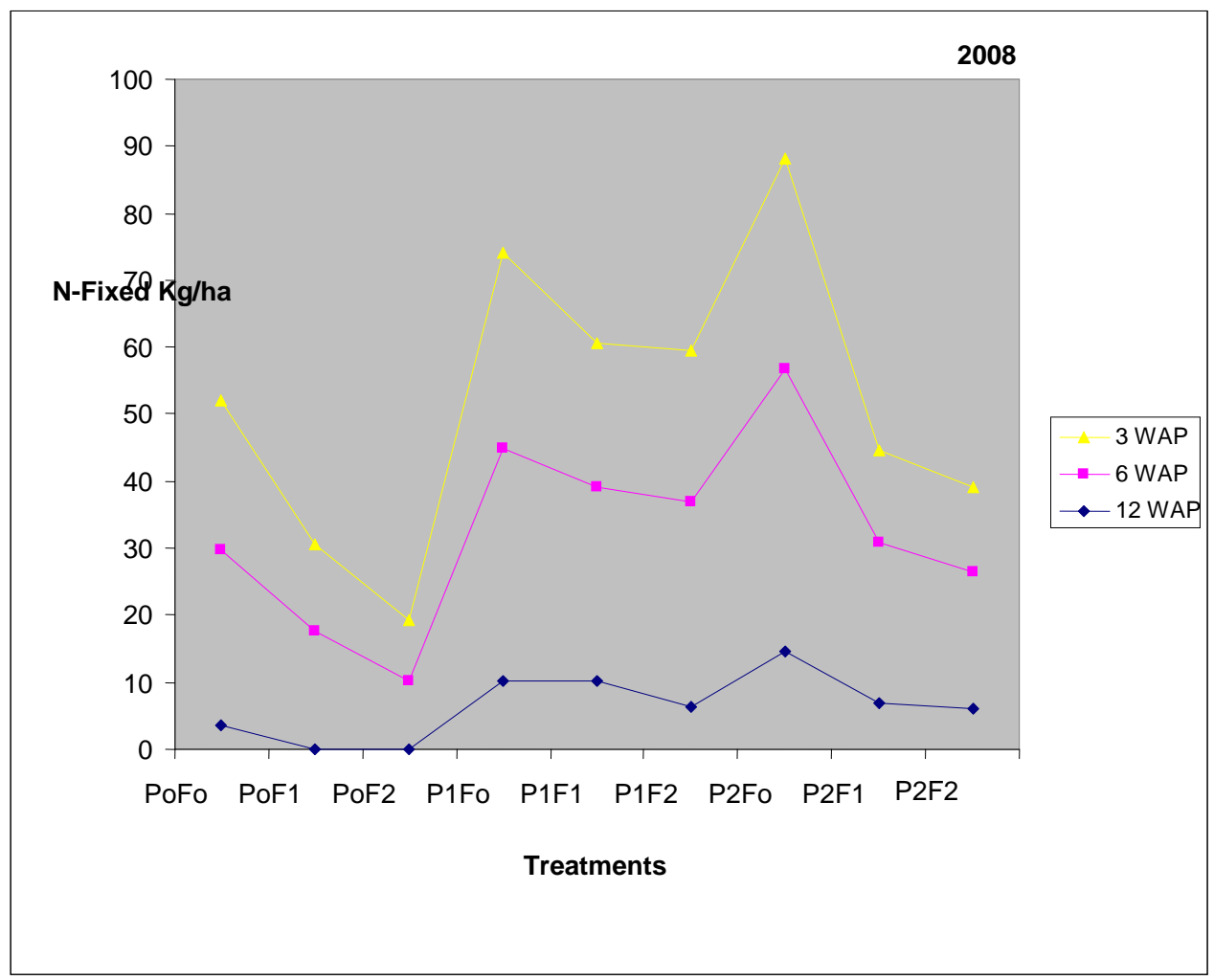


Olatunji, $\mathrm{O}$ and Anjembe B.C.

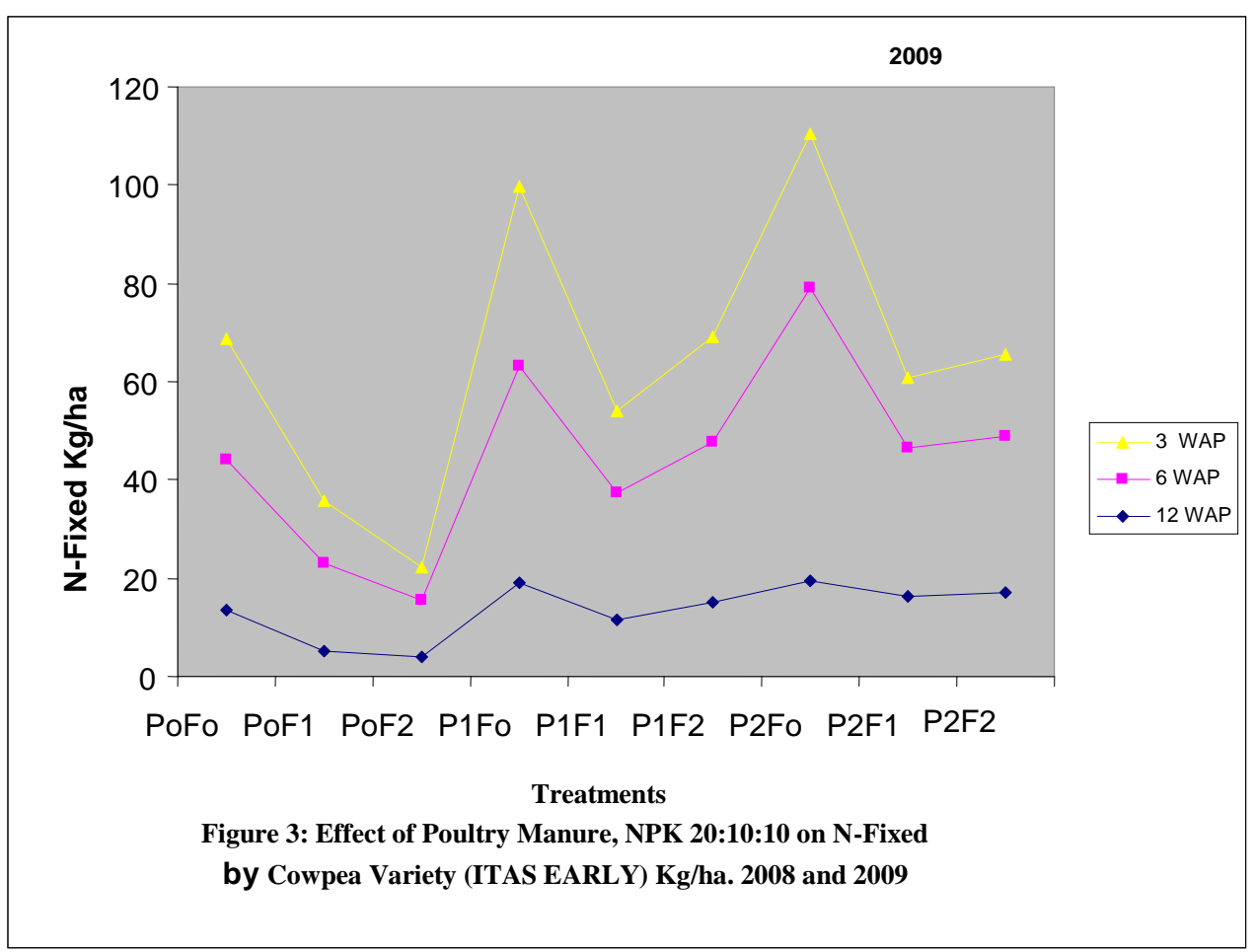

Key:

$\mathrm{P}_{0}-0$ t ha ${ }^{-1}$ poultry manure

$\mathrm{F}_{0^{-}} 0 \mathrm{~kg} \mathrm{~N} \mathrm{ha}^{-1}$ NPK 20-10-10

$\mathrm{P}_{1}-3 \mathrm{t} \mathrm{ha}^{-1}$ poultry manure

$\mathrm{F}_{1}-30 \mathrm{~kg} \mathrm{~N} \mathrm{ha}{ }^{-1}$ NPK 20-10-10

$\mathrm{P}_{2}-6 \mathrm{t} \mathrm{ha}^{-1}$ poultry manure

$\mathrm{F}_{2}-60 \mathrm{~kg} \mathrm{~N} \mathrm{ha}^{-1} \mathrm{NPK} 20-10-10$

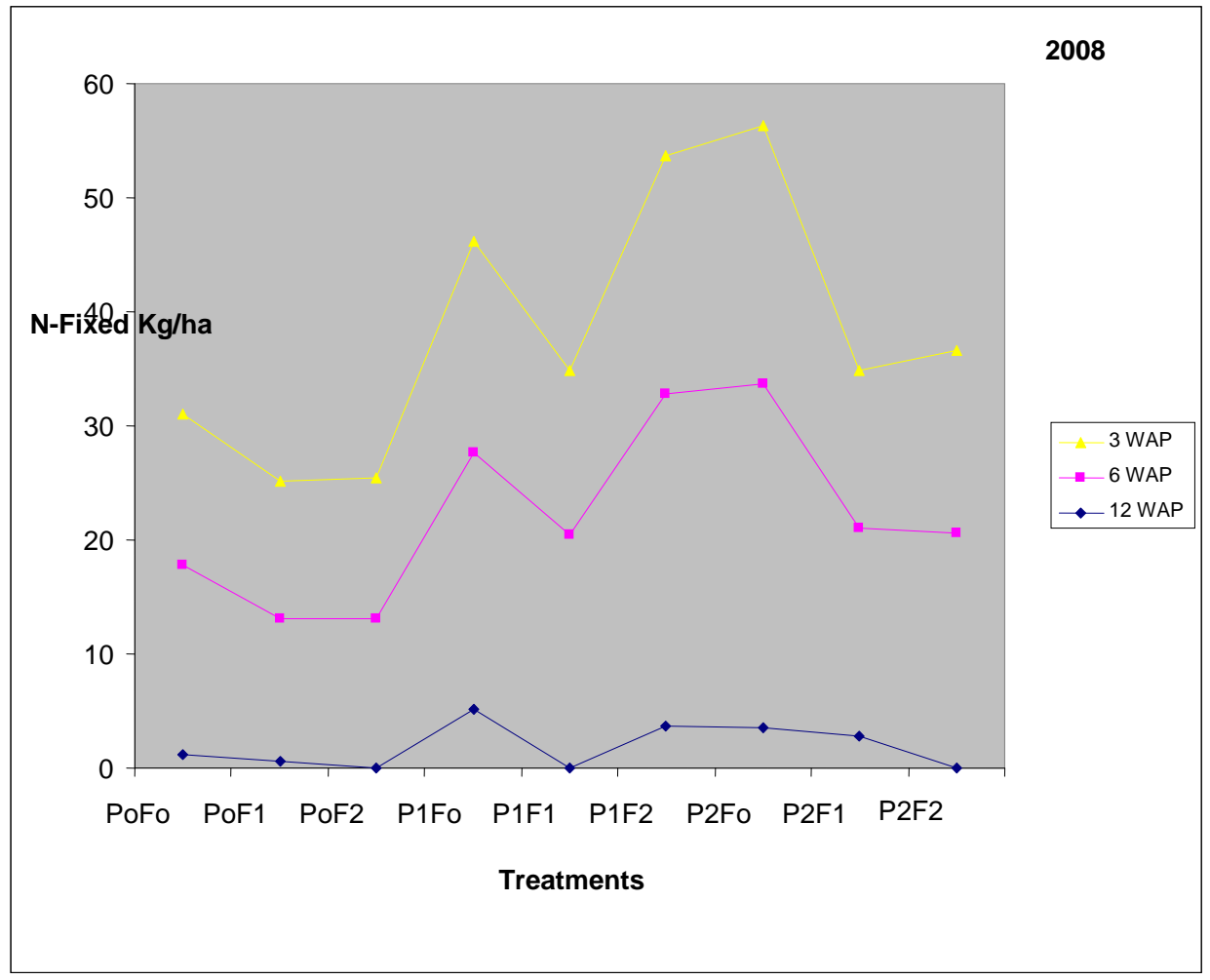




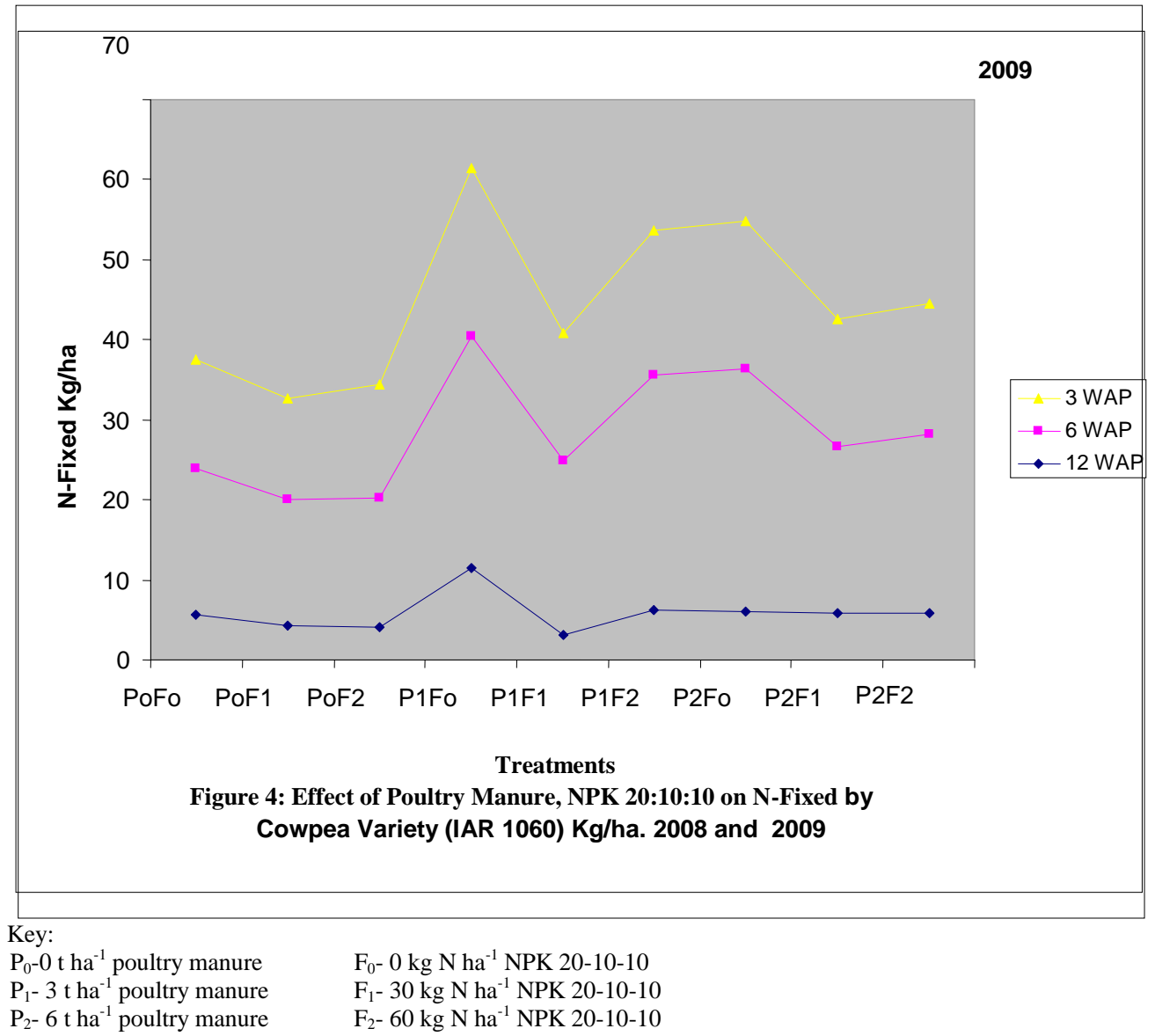

\section{DISCUSSION}

The result obtained in this study seems to suggest that the higher rate of poultry manure in combination with higher rate of NPK 20-10-10 did not lead to increase in cowpea nodulation count which might probably due to high amount of available soil $\mathrm{N}$ from the applied nutrients that resulted in reduced nodulation count. The capacity of cowpea varieties to assimilate soil-N may have been a major determinant of the nodulation count observed, which suggested that the higher the soil $\mathrm{N}$ in terms of mineral fertilizer, the lower the nodulation count that was obtained which corroborated with earlier work by Rhodes, (1981) and Ofori, (1973) that observed that nodulation in cowpea was inhibited by application of $\mathrm{N}$ fertilizer. Also, Graham and Scott, (1984) reported that $\mathrm{N}$ fertilizer at more than $30 \mathrm{~kg} \mathrm{ha}{ }^{-1}$ inhibited nodulation. In addition, Eriksen and Whitney (1984) reported that application of $\mathrm{N}$ at flowering promoted vegetative dry weight but reduced dry weight. Effect of the enriched poultry manure on cowpea varieties shows that negative effect was more pronounced on variety IAR 1060 than ITAS EARLY, and seems to suggest that varietal difference is an important factor in legumes nodulation. The results obtained from this study in terms of enrichment of poultry manure on the amount of $\mathrm{N}$-fixed by cowpea varieties suggested that the higher rate of NPK 20-10-10 will not lead to increase in cowpea N-fixation. The higher $\mathrm{N}$-fixed at 6 WAP for 2008 and 2009 were $42.05 \mathrm{~kg} \mathrm{ha}^{-1}$ and $59.50 \mathrm{~kg} \mathrm{ha}^{-1}$ for variety ITAS EARLY and for IAR 1060 it was $30.15 \mathrm{~kg} \mathrm{ha}^{-1}$ and $30.28 \mathrm{~kg} \mathrm{ha}^{-1}$ obtained from the higher rate of poultry manure and not higher rate of NPK 20-10-10, this seems to suggest that there is probably threshold fertilizer application that will not affect $\mathrm{N}$ fixation. Ojiem et al. (2007) in their study observed declining $\mathrm{N}_{2}$ fixation with declining soil fertility status but Danso and Eskew (1984) asserted that when legumes are grown in soils high in available nitrogen, the nitrogen fixation rate is reduced The reduced $\mathrm{N}$-fixed by cowpea variety (IAR 1060) may be attributed to the genotypic differences of the cowpea varieties. The work of Ojiem et al. (2007) asserted that the amount of $\mathrm{N}_{2}$ fixed by a legume crop varies widely because it depends on the legume genotype, rhizobium strain and the soil environment. In conclusion, cropping system that involves the use of mineral fertilizers, 
organic manure and legumes as biological $\mathrm{N}$ fixer needs to identify legumes species that will continue to fix atmospheric nitrogen even when fertilizer is added. This study suggested that cowpea variety ITAS EARLY may be a much better choice in terms of ability to fix nitrogen fertilizers to the non-leguminous component of a cropping system in the study location.

\section{REFRENCES}

Ande, O. T. Adediran, J. A. Ayoola, O. T. and Akinlosotu, T. A. (2008). Effects of land quality, management and farming systems on cassava production in southwestern Nigeria. African Journal of Biotechnology 17 (4): 2368 - 2374.

AOAC. 1990. Official methods of analysis. Association of official analytical chemists, Washington DC, Pp. 123126.

Bray, R.H. and Kurtz, L.T. 1945. Determination of total organic and available forms of Phosphorus In soils. Soil Science. 59: $39-45$

Bremner, J.M. and Mulvaney, C.S. 1982. Total nitrogen In: Methods of Soil Analysis $2^{\text {nd }}$ ed A.L. Page et al., (Eds.). Pp 595624. ASA, SSSA Madison, Wisconsin.

Bouyoucos, G.S. (1951). A re-calibration of hydrometer method for mechanical analysis of soils, Agronomy Journal 43:434 - 438

Cheruiyot, E.K., Mumera, L.M., Nakhone, L.N., Muonga, S.M. (2003). Effect of legume managed fallow on weed and soil nitrogen in fallowing maize (Zea mays L.) and Wheat (Triticum aestivum L.) crops in the rift valley Islands of Kenya. Australian Journal of Experimental Agriculture, 43: (6) 597 604

Danso, S. K. A. and Eskew, D. L. (1984). Enhancing biological nitrogen fixation. IAEA Bulletin vol. 26 No. 2. Pp $29-$ 35.

Eriksen, F. I. and Whitney, A. (1984). Effects of solar radiation requirements on growth and nitrogen fixation of soybean, cowpea and bush bean. Agron, J. 76:529 - 534.

Giller, K. E., Amijee, F., Brodrick, S. J. and Edje, O. T. (1998). Environmental Constraints to nodulation and nitrogen fixation of Phaselous vulgaris $L$. in Tanzania II. Response to $\mathrm{N}$ and $\mathrm{P}$ fertilizers and inoculation. Afr. J. Crop Sci.
Graham, A. and Scott, R. (1984). Response of cowpea (Vigna unguiculata $(L)$ walp) to nitrogen and inoculation. Trop. Agric. Trinidad 6:56-58.

Hauser, S. (1990). Estimation of symbiotically fixed nitrogen using extended $\mathrm{N}$ difference methods. In: Biological Nitrogen Fixation and sustainability to Tropical Agriculture. Mulongoy, Gueye and Spencer (eds.) Pp. $309-321$.

Kolawole, G.O., G. Tian and B.B. Singh (2002) Differential response of cowpea lines to application of Phosphorus fertilizer In: challenges and opportunities of enhancing sustainable cowpea production, Fatokun, C.A., S.A. Tarawali, B.B. Singh, P.m. Karmawa and M. Tamo (eds.) International Institute for Tropical Agriculture (IITA), Ibadan, Nigeria. Pp 319-328.

Ofori, C. S. (1973). The importance of fertilizer nitrogen in grain legume production soil of gigantic origin in the upper region of Ghana. In proceedings of first IITA Grain Legume Improvement workshop 1973, pp: $155-161$.

Ogoke, I.J., Carsky, R.J. Togun, A.O., K. Dashiel (2001) Maize yield following phosphorus fertilized soybean in the Nigeria guinea savanna. In BaduApraku, B., M. A.B. Fakorede, O. Caulibaly and development in west and central Africa. Proceedings of a Regional Maize workshop, IITACotonou, Benin Republic, 4-7 May, 1999. WECAMAN/IITA. Pp 205-213.

Ojiem, J. O., Vanlauwe, B., de Ridder, N., Giller, K. E. (2007). Niche - based assessment of contributions of legumes to the nitrogen economy of western Kenya small holder farms. Plant soil. 292: 119 - 135 .

Owolade, O.F.,J.A. Adediran, M.A. Akande and B.S. Alabi (2006) Effects of application of phosphorus fertilizer on Brown blotch disease of cowpea. African Journal Biotechnology, 5: 343-347.

Rhodes, E. R. (1981). The economic of fertilizing cowpea (Vigna unguiculata (L) walp) with basic slag on an oxisol in Njala and the effect of the fertilizer on leaf lamina, N. P. Zn contents and nodulation. Trop. Grain Legume Ball. 22: $6-10$.

Walkey, A. and Black, C. A. (1934). An Examination of the Degtjareff method for determining soil organic matter and a proposal modification of chronic acid titration method. Soil Sci. 37: 29 - 38 . 